\title{
Prediction of in vivo Bioavailibility by in vitro Characterization of Ethylenediamine Dipropanoic Acid Derivatives with Cytotoxic Activity
}

\author{
Biljana K. Tubić, ${ }^{1,2,}$ Sandra S. Vladimirov, ${ }^{3}$ Bojan D. Marković ${ }^{3}$ \\ and Tibor J. Sabo ${ }^{4}$ \\ ${ }^{1}$ Agency for Medicines and Medical Devices of Bosnia and Herzegovina \\ ${ }^{2}$ Faculty of Medicine - Department of Pharmacy, University of Banja Luka \\ ${ }^{3}$ Faculty of Pharmacy, University of Belgrade \\ ${ }^{4}$ Faculty of Chemistry, University of Belgrade \\ *Corresponding author:E-mail: b.tubic@almbih.gov.ba; biljana.tubic@unibl.rs \\ Tel.: +38765962309; Fax: +38751450301
}

Received: 25-04-2017

\begin{abstract}
$O, O^{\prime}$-diethyl-(S,S)-ethylenediamine- $N, N^{\prime}$-di-2-(3-cyclohexyl)propanoate (DE-EDCP) is novel substance with cytotoxic activity in human leukemic cells. The aim of this study has been to predict in vivo bioavailability of the DE-EDCP and its potential metabolite (S,S)-ethylenediamine- $N, N^{\prime}$-di-2-(3-cyclohexyl)propanoic acid (EDCP) by in vitro characterization which includes determination of lipophilicity and passive membrane permeability. There has also been evaluated inter-laboratory reproducibility of the bio-analytical method which was previously developed and validated for non-clinical study of the DE-EDCP and EDCP.

Distribution coefficient $n$-octanol/water was 1.68 and 0.03 , and apparent permeability coefficient was $4 \times 10^{-4} \mathrm{~cm} / \mathrm{s}$ and $20 \times 10^{-4} \mathrm{~cm} / \mathrm{s}$, for the DE-EDCP and EDCP, respectively.

Observed results have shown that the DE-EDCP is more lipophilic with better membrane retention, but the EDCP has better pass through the membrane. Also, there has been demonstrated a reproducibility and robustness of the proposed bio-analytical method.
\end{abstract}

Keywords: Transfer of the UHPLC-MS/MS, cross validation, (S,S)-ethylenediamine- $N, N$ '-di-2-(3-cyclohexyl) propanoic acid esters, membrane permeability, lipophilicity

\section{Introduction}

Cytotoxic activity of the novel ester derivatives of the $(S, S)$-1,2-ethanediamine- $N, N^{\prime}$-di-2-(3-cyclohexyl)propanoic acid has been previously proven by the in vitro studies on various leukemic cell lines. It was demonstrated that methyl, ethyl, and n-propyl esters are toxic to HL-60, REH, MOLT-4, KG-1, JVM-2, and K-562 leukemic cell lines, while the non-esterified compound and the $n$-butyl ester are devoid of cytotoxic action. The $O, O^{\prime}$-diethyl-(S,S)-ethylenediamine- $N, N^{\prime}$-di-2-(3-cyclohexyl)propanoate dihydrochloride (DE-EDCP), has showed the highest cytotoxic activity on leukemic cell line HL-60 ( $\mathrm{IC}_{50}$ in the range of $11 \mu \mathrm{M}-45 \mu \mathrm{M})$. Demonstrated data show that the toxicity is mediated by the caspase-independent apoptosis associated with oxidative stress, mitochondrial dysfunction, and AIF translocation. ${ }^{1}$ DE-EDCP has been chosen for further characterization since it had exerted the strongest cytotoxic activity in HL-60 cell line.

In vitro characterization of new pharmaceutical substances includes determination of a lipophilicity and passive membrane permeability. These physicochemical properties of pharmaceutical substances are providing significant information for prediction of the in vivo bioavailability by exploring absorption and distribution behaviour of the substance. Lipophilicity is one of many factors involved in biological activity of a drug, and it is often one of 
the most influential. ${ }^{2}$ Lipophilicity is usually expressed by the $n$-octanol/water partition coefficient $(\log \mathrm{P})$ for neutral molecules and the distribution coefficient $(\log D)$ for ionized molecules. ${ }^{3}$ Method for a determination of the $\log D$ is based on determination of the $n$-octanol/water partition coefficient. ${ }^{2}$ This procedure requires the measurement of the compound concentration in $n$-octanol and water phases after equilibration of both phases according to Eq. (1). Thus, the Eq. (1) can be written as: ${ }^{4}$

$$
\log D=\log \left(\mathrm{c}_{\text {octanol }} / \mathrm{c}_{\text {water }}\right)
$$

where $\mathrm{c}_{\text {octanol }}$ and $\mathrm{c}_{\text {water }}$ are the concentrations of a substance in $n$-octanol and aqueous phase of the partition, respectively.

Method for the in vitro prediction of passive membrane permeability that can be used, is the parallel artificial membrane permeability assay (PAMPA). This method is used extensively for the early drug candidate evaluation. PAMPA was first introduced by Kansy et al. ${ }^{5-8}$

This method has been shown useful in assessing trans-membrane, non-energy dependent, and diffusion of drugs in such a way that a reasonable predictability with in vivo (passive) absorption is possible.

The artificial membrane permeability may be expressed either as a percent of transport $(\% T)$ or as an apparent permeability coefficient $P_{\text {app }}$.

$$
\% T=100 \cdot\left(A_{\mathrm{R}} \cdot V_{\mathrm{R}}\right) /\left(A_{\mathrm{D} 0} \cdot V_{\mathrm{D}}\right)
$$

Where $A_{\mathrm{D} 0}$ and $A_{\mathrm{R}}$ are the peak areas of the initial donor solution and the post-incubation receiving solution (from the acceptor wells), $V_{\mathrm{R}}$ and $V_{\mathrm{D}}$ are the volumes of the receiving and donor solutions. tion:

The $\% T$ is related to $P_{\text {app }}$ based on the following equa-

$$
\begin{aligned}
P_{\text {app }}= & \left(V_{\mathrm{D}} \cdot V_{\mathrm{R}}\right) /\left(\left(V_{\mathrm{D}}+V_{\mathrm{R}}\right) \cdot \mathrm{S} \cdot t\right) \cdot \ln \left[\left(100 \cdot V_{\mathrm{D}}\right)\right. \\
& \left./\left(100 \cdot V_{\mathrm{D}}-\% T\left(V_{\mathrm{D}}+V_{\mathrm{R}}\right)\right)\right]
\end{aligned}
$$

Where $S$ is the surface area of the artificial membrane and $t$ is the incubation time. ${ }^{5}$

Generally, compounds that have a $P_{\text {app }}<10 \times 10^{-6} \mathrm{~cm} /$ $\mathrm{s}$ are classified as low permeability and ones with a $P_{\text {app }}>10$ $\times 10^{-6} \mathrm{~cm} / \mathrm{s}$ are classified as high permeability.

In vivo characterization of new pharmaceutical substances includes non-clinical study on animal model. For non-clinical study of cytotoxic activity of the DE-EDCP and its potential metabolite $(S, S)$-ethylenediamine- $N, N$ '-di-2-(3-cyclohexyl)propanoic acid dihydrochloride (EDCP), there has been previously developed and validated the ultra-high performance liquid chromatography tandem mass spectrometry (UHPLC-MS/MS) bio-analytical method. ${ }^{9}$ Bioanalytical methods should be robust. ${ }^{10}$ Evaluation of reproducibility (transferability) of bio-analytical method is becoming increasingly important ${ }^{11-13}$ since the bio-analytical methods are often used in different laboratories during non-clinical and clinical studies. The transfer process requires the procedure to be physically transferred from a laboratory which masters the technique (called sender or originator) to another site (called receiver or recipient). ${ }^{14}$ In the context of bio-analysis, method transfer is covered by the Food and Drug Administration (FDA) and European Medicines Agency (EMA) guidance documents on bio-analytical method validation. ${ }^{11,13,15}$ Although the need for method transfer is recognized by both authorities, little is said about the process itself. Several approaches have been described for the method transfers evaluation. . $^{12,16-24}$

New UHPLC-MS/MS bio-analytical method which has been developed and validated for the in vivo characterization (non-clinical study) of the DE-EDCP and EDCP, is supposed to be used in different laboratories during the mentioned studies. However, in vitro characterization (lipophilicity and membrane permeability) of the DE-EDCP and EDCP has not been investigated until now.

The aim of this study is to predict the in vivo bioavailability of the DE-EDCP and its potential metabolite EDCP by the in vitro characterization - determination of lipophilicity and passive membrane permeability. In this study, there has also been evaluated the inter-laboratory reproducibility of the previously mentioned bio-analytical method.

\section{Experimental}

\section{1. Chemicals}

$O, O$ '-diethyl-(S,S)-ethylenediamine- $N, N^{\prime}$-di-2-(3-cyclohexyl)propanoate (DE-EDCP), (S,S)-ethylenediami ne$N, N$ '-di-2-(3-cyclohexyl)propanoic acid dihydrochloride (EDCP) and the internal standard (S,S)-O,O'-dibutyl-1,3propanediamine- $N, N^{\prime}$-di-2-(3-cyclohexyl)propanoate dihydrochloride (DB-PDCP), were provided by the Faculty of Chemistry, University of Belgrade, Serbia (Table 1).

Acetonitrile, methanol, ethyl acetate, diethyl ether, triethanolamine, chloroform and trifluoroacetic acid (HPLC grade), ammonium acetate $\left(\mathrm{CH}_{3} \mathrm{COONH}_{4}\right)$, sodium fluoride and $\mathrm{KH}_{2} \mathrm{PO} 4$ (ACS grade) from Fluka (Sigma-Aldrich Co.), $n$-octanol from Fluka AG (Buchs SG, Switzeland) and deionized water (TKA GenPure Ultrapure, Germany), were used. Mouse serum was purchased from Sigma Aldrich (Saint Louis, USA).

\section{2. Solutions}

Preparation of all standard solutions is described in a previously published study. ${ }^{9}$ Sample preparation is also described previously. ${ }^{9}$ All these solutions were prepared by two different analysts in sending and receiving laboratories.

\section{3. Equipment}

Solids were weighted by using a 5-digit Mettler analytical balance (Mettler-Toledo International Inc, USA), 
Table 1: Structure of EDCP, DE-EDCP, and the internal standard DB-PDCP

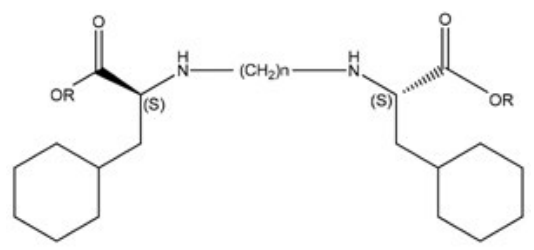

\begin{tabular}{|c|c|c|c|c|c|}
\hline Name of compound & $\begin{array}{l}\text { Empirical } \\
\text { formula }\end{array}$ & Abbreviation & $\begin{array}{c}\text { MW } \\
(\mathrm{g} / \mathrm{mol})\end{array}$ & $\mathbf{R}$ & $\mathbf{n}$ \\
\hline $\begin{array}{l}(S, S) \text {-ethylenediamine- } N, N^{\prime} \text {-di-2-(3-cyclohexyl)propanoic } \\
\text { acid dihydrochloride }\end{array}$ & $\mathrm{C}_{20} \mathrm{H}_{38} \mathrm{O}_{4} \mathrm{~N}_{2} \mathrm{Cl}_{2}$ & EDCP & 441.43 & $\mathrm{H}$ & 2 \\
\hline $\begin{array}{l}O, O^{\prime} \text {-diethyl- }(S, S) \text {-ethylenediamine- } N, N^{\prime} \text {-di-2- } \mathrm{C}_{24} \mathrm{H}_{46} \mathrm{O}_{4} \mathrm{~N}_{2} \mathrm{Cl}_{2} \\
\text { (3-cyclohexyl)propanoate dihydrochloride }\end{array}$ & DE-EDCP & 497.54 & $\mathrm{C}_{2} \mathrm{H}_{5}$ & 2 & \\
\hline $\begin{array}{l}(S, S) \text {-O, } O^{\prime} \text {-dibutyl-1,3-propanediamine- } N, N^{\prime} \text {-di-2- } \\
\text { (3-cyclohexyl)propanoate dihydrochloride }\end{array}$ & $\mathrm{C}_{29} \mathrm{H}_{56} \mathrm{O}_{4} \mathrm{~N}_{2} \mathrm{Cl}_{2}$ & DB-PDCP & 567.67 & $\mathrm{C}_{4} \mathrm{H}_{9}$ & 3 \\
\hline
\end{tabular}

and less sensitive weighting was performed on the Adventurer Pro analytical balance (OHAUS, USA). Sample preparation was done by using the Eppendorf 5417R micro-centrifuge (Eppendorf, Germany).

\section{4. Sending Laboratory}

Development and validation of the method was done in the sending laboratory on the Thermo ACCELA (Thermo Scientific, Waltham, Massachusetts, USA) UHPLC system, coupled to a triple quad Mass Spectrometer Thermo TSQ Quantum Access Max (Thermo Scientific, Waltham, Massachusetts, USA), with a heated electro-spray ionization (HESI) interface. ${ }^{24} \mathrm{~A}$ reverse-phase Thermo Scientific Hypersil GOLD aQ column $(100 \times 2.1 \mathrm{~mm} 1.9 \mu \mathrm{m}$ ThermoScientific, and guard cartridge (Thermo Scientific Hypersil GOLD aQ, $10 \mathrm{~mm} 1 \times 4 \mathrm{~mm} \mathrm{ID)}$ ), were used in both laboratories.

\section{5. Receiving Laboratory}

In the receiving laboratory, method transfer and validation were carried out on the Agilent 1290 UHPLC system equipped with the Agilent 6420 triple-quad mass detector (Agilent Technologies, Santa Clara, USA) with the electro-spray ionization (ESI) interface.

DE-EDCP, EDCP and IS were eluted by using a mobile phase as previously described..$^{9}$ Quantitation was achieved by the MS-MS detection in the positive ionization mode for the DE-EDCP, EDCP and IS. The MS operating conditions were optimized as following: the capillary voltage was $4500 \mathrm{~V}$, the gas temperature was set to $340{ }^{\circ} \mathrm{C}$ and gas flow was $10 \mathrm{l} / \mathrm{min}$ and the nebulizer pressure was 35 psi. Nitrogen was used as a collision gas. Fragmented voltage was set to $135 \mathrm{~V}$. Ions detection was performed in the multiple reaction monitoring (MRM) by using the following transitions of $\mathrm{m} / z 425.2 \rightarrow 197.8$ and 226.1 for DE-EDCP, $m / z 369.3 \rightarrow 152.1$ and 198.1 for EDCP and $\mathrm{m} / z$
$495.3 \rightarrow 166.0$ and 268.1 for DB-PDCP (IS), respectively, with a scan time of $0.1 \mathrm{~s}$ per transition.

Mass Hunter Optimizer software version 6.00 (Agilent Technologies, Santa Clara, USA) was used for automatic optimization of the acquisition parameters. Data Acquisition was performed by using the Mass Hunter Data Acquisition software version 6.00 (Agilent Technologies, Santa Clara, USA).

Qualitative and quantitative data analyses were done by using the Mass Hunter Qualitative software version 6.00 and Mass Hunter Quantitative software version 6.00 (Agilent Technologies, Santa Clara, USA), respectively.

Method transfer was done from the sending laboratory to the receiving laboratory.

The cross-validation samples were analyzed through a fully validated bio-analytical method at the receiving laboratory along with the calibration of the standards and QC samples for the validity of each analytical run. The following validation parameters were evaluated in the receiving laboratory for the UHPLC-MS/MS system: selectivity, linearity, limit of quantification (LLOQ), recovery, accuracy, precision and matrix effects.

Also, cross-validation samples were analyzed by the Passing and Bablok regression analysis. Passing and Bablok regression analysis is a statistical procedure which allows the valuable estimation of the analytical methods agreement and possible systematic bias between them. Results are presented with a scatter diagram and a regression line, as well as a regression equation where an intercept represents a constant and slope proportional measurement error. Confidence intervals of $95 \%$ of the intercept and slope, give the explanation whether their value differ from the value zero (intercept) and value one (slope) only by chance, allowing a conclusion of the method agreement and a correction action, if necessary. ${ }^{25}$

During this study, there have been tested the selectivity, linearity, limit of quantification (LLOQ), recovery (\%), matrix effects, accuracy and precision, as described previously. ${ }^{9}$ 
Cross-validation showed to be successful in terms of the results' traceability between the two instruments (slope and intercept with confidential interval values) and the results of validation parameters (selectivity, linearity, limit of quantification (LLOQ), recovery, accuracy, precision and matrix effects).

\section{6. Determination of the $n$-octanol/water Distribution Coefficient $(\log D)$}

$\log D$ values were determined by using a shake-flask method. In the shake-flask experiment, $5 \mathrm{mg}$ of each substance (DE-EDCP and EDCP) was first mixed with $50 \mathrm{ml}$ of aqueous buffer ( $\mathrm{pH} 7.4$ ). Then, $10 \mathrm{ml}$ of this solution was mixed with $10 \mathrm{ml}$ of the $n$-octanol (water saturated). The sample vial was placed on the shaker and been shaken for $12 \mathrm{~h}$ at $250 \mathrm{rpm}$. After equilibration, it was left to stand for $2 \mathrm{~h}$ to phases well separated.

The separated aqueous phase is being centrifuged, the residual drops of the $n$-octanol to be eliminated. The aqueous phase was sampled and assayed by the transferred and cross-validated UHPLC-MS/MS which had been previously validated for the determination of the investigated substances in the aqueous buffer ( $\mathrm{pH}$ 7.4) in order to determine the $\log D$ value. The concentration of the investigated substances in the $n$-octanol phase was obtained as a difference in the concentrations in the aqueous buffer, prior to mixing with the $n$-octanol and after mixing with the $n$-octanol.

\section{7. Prediction of Membrane Permeability (PAMPA test)}

The in vitro method for the prediction of membrane permeability which was used in these studies, was carried out in a 96-well format. 96-well micro-titer plates (hydrophobic PVDF MultiScreen IPFilter Plate $0.45 \mu \mathrm{m}$, from Milipore (Bedford, MA, USA)), were assembled into such a "sandwich" that each composite well was separated by a $125 \mu \mathrm{m}$ micro filter disc. Filter material in each well of the filtration plate was wetted with $5 \mu$ of the artificial membrane solution, which consisted of $1 \%$ egg lecithin in the $n$-dodecane. Subsequently, the filter plate was placed on the bottom micro-titer plate containing the following donor solution: $300 \mu \mathrm{l}$ of the compound in the concentration of $0.1 \mathrm{mg} / \mathrm{ml}$ dissolved in the buffer $\mathrm{KH}_{2} \mathrm{PO}_{4} 0.2 \mathrm{M}, \mathrm{pH}=$ 7.4. The top acceptor wells of the sandwich, were hydrated with the $300 \mu \mathrm{l}$ of the buffer $\mathrm{KH}_{2} \mathrm{PO}_{4} 0.2 \mathrm{M}$, pH 7.4. To prevent loss by evaporation, the system was first covered with a paraffinic film. The surface area of the artificial membrane was $S=0.28 \mathrm{~cm}^{2}$ and the period of incubation was $\mathrm{t}$ $=7200 \mathrm{~s}(2 \mathrm{~h})$.

After incubation, the amount of the DE-EDCP and EDCP in the donor and acceptor wells, was determined by the UHPLC-MS/MS method which had been previously transferred and cross-validated.

\section{8. Software}

For the determination of lipophilicity $\left(\log D_{7.4}\right)$ of the investigated substances by the in silico model, there was used the MarvinSketch 4.1.13 (ChemAxon, Budapest, Hungary).

\section{Results and Discussion}

\section{1. UHPLC-MS/MS Method: Transfer and Cross-validation}

Transfer of the ultra-high performance liquid chromatography-electro-spray tandem mass spectrometry (UHPLC-ESI-MS/MS) method for non-clinical studies and the in vitro characterization of recently synthesized substances with the cytotoxic activity, DE-EDCP and its potential metabolite EDCP, in biological material, was carried out. The reproducibility and transferability of this bio-analytical method in the mouse serum was evaluated by the validation and cross-validation of the method through using two different UHPLC-MS/MS systems. The parallel displayed values of the observed validation parameters are given in the Table 2.

The method was proven to be highly selective for the analytes, since no interfering peaks from the endogenous compounds were observed at the retention times for the DE-EDCP and EDCP in any of the six independent blank serum extracts evaluated.

Also, cross-validation samples analyzed by the Passing and Bablok regression analysis, showed to be successful in terms of the results' traceability between the two instruments (for DE-EDCP: slope $=0.9821$ with lower $95 \%$-CL $=$ 0.7737 and upper $95 \%-\mathrm{CL}=1.1685$, and intercept $=0.0547$ with lower $95 \%-\mathrm{CL}=-5.1662$ and upper $95 \%-\mathrm{CL}=3.4285$; for EDCP: slope $=1.0187$ with lower $95 \%-C L=0.9522$ and upper $95 \%-\mathrm{CL}=1.1505$, and intercept $=-0.0488$ with lower $95 \%-\mathrm{CL}=-0.5347$ and upper $95 \%-\mathrm{CL}=0.2187$ ).

Overall results of the cross-validation were satisfactory in terms of all the investigated parameters proving that the method can be successfully transferred under the aforementioned conditions. Results of the validation and cross validation demonstrate that the novel UHPLC-MS/ MS method for the in vivo characterization (non-clinical study) of the novel DE-EDCP and EDCP substances with cytotoxic activity, is appropriately transferred and validated at the receiving laboratory.

\section{2. Validation of the UHPLC-MS/MS in the Aqueous Buffer}

The observed UHPLC-MS/MS method was successfully validated for the determination of the investigated substances DE-EDCP and EDCP from an aqueous buffer ( $\mathrm{pH}$ 7.4). Results of the validation parameters are given in the Table 3. 
Table 2: Validation parameters for the DE-EDCP and EDCP on the Thermo ACCELA and the Agilent 1290 UHPLC system

\begin{tabular}{|c|c|c|c|c|}
\hline \multirow[t]{2}{*}{ Validation parameter } & \multicolumn{2}{|c|}{ Sending laboratory (Thermo ACCELA) } & \multicolumn{2}{|c|}{$\begin{array}{c}\text { Receiving laboratory } \\
\text { (Agilent } 1290 \text { UHPLC system) }\end{array}$} \\
\hline & DE-EDCP & EDCP & DE-EDCP & EDCP \\
\hline Linearity of calibration curves & $\begin{array}{l}1.326 .7 \mathrm{ng} / \mathrm{ml} \\
y=0.0461 x+0.0895 \\
r=0.9978\end{array}$ & $\begin{array}{l}0.33-6.67 \mu \mathrm{g} / \mathrm{ml} \\
y=0.1527 x+0.0045 \\
r=0.9987\end{array}$ & $\begin{array}{l}3.3-26.7 \mathrm{ng} / \mathrm{ml} \\
y=64.243 x+114.54 \\
r=0.9983\end{array}$ & $\begin{array}{l}0.33-6.67 \mu \mathrm{g} / \mathrm{ml} \\
y=9322.3 x-103.4, \\
r=0.9989\end{array}$ \\
\hline $\begin{array}{l}\text { LLOQ } \\
\text { Recovery \% } \\
\text { Matrix effect } \\
\end{array}$ & $\begin{array}{l}1.3 \mathrm{ng} / \mathrm{ml} \\
90.0-99.3 \\
95.5-108.2 \% \\
\end{array}$ & $\begin{array}{l}0.33 \mu \mathrm{g} / \mathrm{ml} \\
75.8-100.3\end{array}$ & $\begin{array}{l}3.3 \mathrm{ng} / \mathrm{ml} \\
91.0-99.8 \\
96.7-109.4 \% \\
\end{array}$ & $\begin{array}{l}0.33 \mu \mathrm{g} / \mathrm{ml} \\
77.8-101.5\end{array}$ \\
\hline Precision $(\% \mathrm{CV})$ & $\begin{array}{r}15.99 \\
13.68 \\
2.25 \\
3.49\end{array}$ & $\begin{array}{l}5.58 \\
4.43 \\
5.32 \\
4.01\end{array}$ & $\begin{array}{l}3.22 \\
3.36 \\
3.97 \\
1.87\end{array}$ & $\begin{array}{l}4.00 \\
2.05 \\
3.95 \\
2.00\end{array}$ \\
\hline Accuracy (\%RE) & $\begin{array}{r}3.01 \\
12.61 \\
6.30 \\
1.80\end{array}$ & $\begin{array}{r}6.06 \\
-2.41 \\
-3.20 \\
-14.40\end{array}$ & $\begin{array}{r}17.05 \\
11.50 \\
5.20 \\
1.73\end{array}$ & $\begin{array}{r}-9.93 \\
-14.52 \\
-13.13 \\
-14.20\end{array}$ \\
\hline
\end{tabular}

$\mathrm{y}$ represents the peak area ratio of analyst to IS

Table 3: Validation parameters for the DE-EDCP and EDCP in an aqueous buffer, without a biological matrix (Thermo ACCELA)

\begin{tabular}{lll}
\hline $\begin{array}{l}\text { Validation } \\
\text { parameter }\end{array}$ & \multicolumn{2}{c}{ Thermo ACCELA } \\
\hline Linearity of & 2.0 to $40.0 \mathrm{ng} / \mathrm{ml}$ & 0.5 to $10.0 \mu \mathrm{g} / \mathrm{ml}$ \\
calibration curves & $r=0.9930$ & $r=0.9997$ \\
LLOQ & $2.0 \mathrm{ng} / \mathrm{ml}$ & $0.50 \mu \mathrm{g} / \mathrm{ml}$ \\
Precision (\%CV) & 3.29 to $18.07 \%$ & 6.09 to $15.50 \%$ \\
Accuracy (\%RE) & 0.01 to $16.00 \%$ & 1.48 to $13.50 \%$ \\
\hline
\end{tabular}

\section{3. Determination of the $\log D_{7.4}$ in vitro/in silico and the PAMPA Test}

Lipophilicity of the observed substances DE-EDCP and EDCP, has been tested by the traditional shake-flask method. Passive membrane permeability has been tested by the PAMPA test. Experimental results that have been obtained in this study are shown in the Table 4 . Also, in the Table 4, there can be seen in silico results of the lipophilicity of the DE-EDCP and EDCP.

Table 4: Lipophilicity and passive membrane permeability data for the investigated substances DE-EDCP and EDCP

\begin{tabular}{lccccc}
\hline $\begin{array}{l}\text { Com- } \\
\text { pound }\end{array}$ & $\begin{array}{c}\text { Log } \\
\boldsymbol{D}_{7.4}^{*}\end{array}$ & $\begin{array}{c}\text { Log } \\
\boldsymbol{D}_{7.4}\end{array}$ & $\begin{array}{c}\boldsymbol{P}_{\text {app }} \\
(\mathbf{c m} / \mathbf{s})\end{array}$ & $\begin{array}{c}\text { \% } \boldsymbol{T} \\
\text { \% Membrane } \\
\text { retention }\end{array}$ \\
\hline EDCP & -1.8 & 0.03 & $20^{\star} 10^{-4}$ & 7.94 & 6.90 \\
DE-EDCP & 4.04 & 1.68 & $4^{\star} 10^{-4}$ & 1.76 & 97.46 \\
\hline
\end{tabular}

* by MarvinSketch 4.1.13

The results represent obvious difference in the lipophilicity between the DE-EDCP and EDCP. Lipophilicity data obtained through the shake flask method, and membrane permeability data acquired by the PAMPA test, are correlated with the results gained in the previous in vitro activity studies on various leukemic cell lines of the investigated compounds. Compound DE-EDCP with a significant cytotoxic activity, ${ }^{1}$ has greater lipophilicity which allows more retention in the cell membrane. This characteristic of the aforementioned compound is particularly important for its activity. On the other hand, the suspected metabolite EDCP is more hydrophilic and passes through the membrane, without retention in the cell membrane.

\section{Conclusions}

In this study, DE-EDCP and EDCP bioavailability was examined through in vitro characterization, by determination of lipophilicity and passive membrane permeability. Observed results are showing that the DE-EDCP is more lipophilic than the EDCP, with better membrane retention.

Additionally, this study proved good reproducibility (transferability) and robustness of the bioanalytical method for in vivo characterization of the investigated substances.

\section{Acknowledgements}

This work was partly supported by the Ministry of Education, Science and Technological Development of the Republic of Serbia, as a part of the Projects No. 172041 and No. 175035. One of the authors (B.T.) is thankful to the Ministry of Science and Technology of the Republic of Srpska for funding the study through the Project 19/6020/961-169/14. 


\section{References}

1. S. Misirlić Denčić, J. Poljrević, U. Vilimanovich, A. Bogdanović, J. A. Isaković, T. Kravić Stevović, M. Dulovic, N. Zogovic, M. A. Isaković, S. Grguric-Sipka, V. Bumbasirević, T. Sabo, V. Trajković, I. Marković, Chem Res Toxicol. 2012, 25, 931-939. DOI:10.1021/tx3000329

2. E. Rutkowska, K. Pajak, K. Jozwiak, Acta Pol Pharm - Drug Research. 2013, 70, 3-18.

3. X. Xuan, L. Xu, L. Li, C. Gao, N. Li, Int J Pharm.2015, 490, 258-264. DOI:10.1016/j.ijpharm.2015.05.019

4. A. Andres, M. Roses, C. Rafols, E. Bosch, S. Espinosa, V. Segarra, J. M. Huerta, Eur J Pharm Sci. 2015, 76, 181-191. DOI:10.1016/j.ejps.2015.05.008

5. C. Zhu, L. Jiang, M. T. Chen, K. K. Hwang, Eur J Med Chem. 2002, 37, 399-407. DOI:10.1016/S0223-5234(02)01360-0

6. M. Kansy, F. Senner, K. Gubernator, J Med Chem. 1998, 41, 1107-1110. DOI:10.1021/jm970530e

7. K. Sugano, H. Hamada, M. Machida, H. Ushio, J Biomol Screen. 2001, 6, 189-196.

DOI:10.1177/108705710100600309

8. F. Wohnsland, B. Faller, J Med Chem. 2001, 44, 923-930. DOI:10.1021/jm001020e

9. B. Tubić, B. Marković, S. Vladimirov, S. Ristić, B. Ivković, M. Savić, J. Poljarević, T. Sabo, Acta Chromatogr. http://www. akademiai.com/doi/pdf/10.1556/1326.2017.29.2.7 (assessed: April 24, 2017)

10. T. Yoneyama, T. Kudo, F. Jinno, R. E. Schmidt, T. Kondo, The AAPS Journal. 2014, 16, 1226-1236.

DOI:10.1208/s12248-014-9653-0

11. M. H. Hill, G. Smith, Bioanalysis.2015, 7(7), 783-787. DOI:10.4155/bio.15.37

12. A. K. Shah, T. H. Karnes, J Chromatogr B. 2009, 877, 22702274. DOI:10.1016/j.jchromb.2009.04.020

13. Food and Drug Administration, Guidance for Industry: Bioanalytical Method Validation U.S. Department of Health and Human Services Food and Drug Administration Center for Drug Evaluation and Research (CDER) Center for Vet- erinary Medicine (CVM) BP http://www.fda.gov/downloads/ Drugs/.../Guidances/ucm070107.pdf (assessed: April 24, 2017)

14. E. Rozet, W. Dewe, R. Morello, P. Chaip, F. Lecomte, E. Ziemons, S. K. Boos, B. Boulanger, J. Crommen, Ph. Hubert, J Chromatogr A. 2008, 1189, 32-41.

DOI:10.1016/j.chroma.2007.11.029

15. European Medicines Agency,Guideline on bioanalytical method validation Doc. Ref: EMEA/CHMP/EWP/192217/2009 Rev. 1 Corr. $2^{* *}$ http://www.ema.europa.eu/docs/en_ GB/document_library/Scientific_guideline/2011/08/ WC500109686.pdf (assessed: April 24, 2017)

16. International Society for Pharmaceutical Engineering,Good Practice Guide: Technology Transfer (Second Edition) http:// www.ispe.org/ispe-good-practice-guides/technology-transfer (assessed: April 24, 2017)

17.U. Schepers, H. Watzig, J Pharmaceut Biomed. 2005, 39, 310 314. DOI:10.1016/j.jpba.2005.03.015

18. W. Dewe, B. Govaerts, B. Boulanger, E. Rozet, P. Chiap, Ph. Hubert, Chemometr Intell Lab.2007, 85, 262-268.

DOI:10.1016/j.chemolab.2006.07.003

19. C. Hartmann, J. Smayers-Verbeke, W. Penninckx, Y. Vander Heyden, P. Vankeerberghen, L. D. Massart, Anal Chem. 1995, 67, 4491-4499. DOI:10.1021/ac00120a011

20. D. Chambers, G. Kelly, G. Limentani, A. Lister, R. Lung, E. Warner, J Pharm Technol. 2005, 9, 64-80.

21.U. Schepers, H. Watzig, J Pharmaceut Biomed. 2006, 41, 290 292. DOI:10.1016/j.jpba.2005.10.030

22.S. Feng, Q. Liang, D. R. Kinser, K. Newland, R. Guilbaud, Anal. Bioanal. Chem. 2006, 385, 975-981.

DOI:10.1007/s00216-006-0417-2

23. J. Vial, A. Jardy, P. Anger, A. Braun, J. Manet, J Chromatogr A. 1998, 815, 173-182.

DOI:10.1016/S0021-9673(98)00510-X

24. G. de Fontenay, J Pharmaceut Biomed. 2008, 46, 104-112. DOI:10.1016/j.jpba.2007.09.007

25. L. Bilić-Zulle, Biochemia Medica. 2011, 21(1), 49-52. DOI:10.11613/BM.2011.010

\section{Povzetek}

(S,S)-O, O-dietil-1,2-etandiamin- $N, N^{\prime}$-di-2-(3-cikloheksil)propanoat (DE-EDCP) je nova snov s citotoksično aktivnostjo v človeških levkemičnih celicah. Cilj te študije je bil napovedovanje in vivo biološke uporabnosti DE-EDCP in njegovega potencialnega metabolita $(S, S)$-1,2-etandiamina- $N, N^{\prime}$-di-2-(3-cikloheksil) propanojske kisline EDCP) z in vitro karakterizacijo, ki vključuje določanje lipofilnosti in pasivne membranske prepustnosti. Ocenjena je bila medlaboratorijska obnovljivost biološke analitske metode, ki je bila predhodno razvita in potrjena za neklinično študijo DE-EDCP in EDCP.

Porazdelitveni koeficient med $n$-oktanolom in vodo je bil 1,68 in 0,03, navidezni koeficient prepustnosti pa je bil 4 $\times 10^{-4} \mathrm{~cm} / \mathrm{s}$ in $20 \times 10^{-4} \mathrm{~cm} / \mathrm{s}$ za DE-EDCP in EDCP.

Opaženi rezultati so pokazali, da je DE-EDCP bolj lipofilen z boljšim zadrževanjem v membrani, medtem ko EDCP bolje prehaja skozi membrano. Lahko domnevamo, da je mehanizem citotoksične aktivnosti DE-EDCP na ravni celične membrane. Dokazana je bila ponovljivost in robustnost predlagane bioanalitične metode. 